${ }^{\circledR}$ Entomol. Fennica. 5 December 1995

\title{
Distribution maps of the outdoor myrmicid ants (Hymenoptera, Formicidae) of Finland, with notes on their taxonomy and ecology
}

\author{
Michael I. Saaristo
}

Saaristo, M. I. 1995: Distribution maps of the outdoor myrmicid ants (Hymenoptera, Formicidae) of Finland, with notes on their taxonomy and ecology. — Entomol. Fennica 6:153-162.

Twentytwo species of myrmicid ants maintaining outdoor populations are listed for Finland. Four of them, Myrmica hellenica Forel, Myrmica microrubra Seifert, Leptothorax interruptus (Schenck), and Leptothorax kutteri Buschinger are new to Finland. Myrmica lonae Finzi is considered as a good sister species of Myrmica sabuleti Meinert, under which name the species has earlier been known in Finland. Myrmica specioides Bondroit is deleted from the list as no samples of this species could be located in the collections. The distribution of each species in Finland is presented on $10 \times 10 \mathrm{~km}$ square grid maps. The ecology of the various species is discussed. Also some taxonomic problems are dealt with.

Michael I. Saaristo, Zoological Museum, University of Turku, FIN-20500 Turku, Finland

This study was started during the autumn of 1983 , by determing the extensive pitfall material of ants in the collections of the Zoological Museum of the University of Turku (MZT). About the same time the ant collections of the Finnish Museum of Natural History, Helsinki (MZH) and the Department of Applied Zoology, University of Helsinki (DAZH) were also carefully checked. As a result of these studies it was found that information on the distribution of most of the Finnish myrmicids was still very sporadic. Therefore numerous, specially planned ant collecting trips were made by the author in 1985-94.

In addition to more detailed picture of the distribution of the Finnish myrmicids, these trips also yielded four new myrmicid ants for the Finnish fauna, viz. Myrmica hellenica, M. microrubra, Leptothorax interruptus, and L. kutteri.

Myrmicids are commonly known to include numerous social parasites. Alltogether six of them are now known to exist in Finland: Myrmica hirsuta, Myrmica microrubra, Symbiomyrma karavajevi, Leptothorax kutteri, Harpagoxenus sublaevis, and
Anergates atratulus. One of them, viz. H. sublaevis, is a dulotic or slave keeping-species with a specialized soldier-like worker caste, while others have no workers at all. As usual with workerless social parasites, there are quite few records of them because they are difficult to collect except during the relatively short time when they have alates. Therefore, they most probably are more widely spread than the present data would suggest. This assumption may be infered from the results obtained with L. kutteri, to which special attention was paid. This was done by bringing numerous $L$. acervorum nests in plastic bags to the laboratory where they were reared in order to learn if they possibly included $L$. kutteri.

In addition to the actual social parasites, one xenobiotic species, Formicoxenus nitidulus, is found in Finland. This small species lives only in the nests of mound bilding red wood ants (Formica rufa group).

Finally, it should be noted that Myrmica specioides Bondroit, 1918 have been deleted from the list of Finnish myrmicids. The only sample 
identified as that species proved to be a misidentification of Myrmica scabrinodis.

\section{The species, with ecological and taxo- nomic notes}

\section{Myrmica gallienii Bondroit, 1919 (Map 1)}

As stated earlier by Jacobson (1939, as $M$. rolandi Bondroit, 1918) and later also by Seifert (1988), $M$. gallienii has been frequently confused with $M$. rugulosa, $M$. rubra, $M$. ruginodis and even with $M$. sulcinodis. According to my own experience this is true of all castes of $M$. rugulosa and also particularly to the worker caste of $M$. rubra and also $M$. ruginodis.

Earlier (Collingwood 1979) only one sample of this species had been identified from Finland (Hanko, Täktom, 6ððð, Håkan Lindberg leg.). During this study, additional samples were found among the old material determined either as $M$. rubra or $M$. rugulosa. Also, three new nesting sites were located; two of them in considerably northern localities. At present, the species has been found in the following five places in Finland:

1. Hanko, Täktom, 1945, 1ழ7ఫ̧ઠ, leg. Håkan

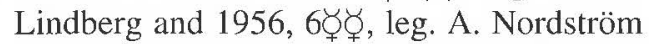
$(\mathrm{MZH})$.

2. Finström, Åttböle, 31.V.1945, 1ð̋, leg. A. Nordström (MZT).

3. Sund, Stenrösberget Stormyran, 30.VII.1987, 1४̧, leg. M. Saaristo (MZT)

4. Oravainen, Bodholm, 1966, numerous $\not \Varangle \not \&$ one mosaic gynadromorph, leg. P. T. Lehtinen

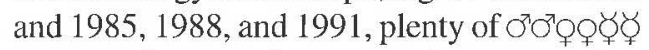
and mosaic gynandromorphs, leg. M. Saaristo (MZT).

5. Lohtaja, Vattajanniemi, 1.VI.1988, numerous фơ̧૪, leg. M. Saaristo (MZT).

The nesting site of $M$. gallienii in Oravainen was originally discovered when studying the pitfall trap material of MZT. During the summer of 1966 some 10 traps were placed in a silty seashore meadow more or less regularly flooded during the spring and autumn. This is in good agreement with Seifert's (1993b) statement that M. gallienii is a facultatively halophilic, thermophilic and clearly hygrophilic species. The site was visited by the author 7.VIII. 1985 and a flourishing M. gallienii population was verified. It covered about 5 ares and consisted of over one hundred nests. They were rather big earth mounds resembling those of Lasius flavus (Fabricius, 1781). Some of the surrounding herbs were growing through the nests and the slightest disturbance of them caused the ants to come swiftly out of the nests and cover the nests in a tight crawling mass. The nests were very populous, consisting of several thousand workers, and at that time there were also plenty of males and females. On 1.VI.1988 the site was visited again and the $M$. gallienii population was still doing well. During the same ant collecting trip a new $M$. gallienii population was discovered in Lohtaja some $80 \mathrm{~km}$ north of Oravainen. This time the site was a costal sand dune area and nests were bored some $10 \mathrm{~cm}$ deep into the sand. Time did not permit a more careful study of the area and accordingly only a few nests were located. Although it was not the normal time for alates there were numerous winged females in one of the nests. Already Jacobson (1938) have stated that when the nests are in dry, sandy places they are buried in soil while, in more wet surroundings they are built as mounds.

A very interesting, and at the same time strange situation was observed concerning the production of sexuals in the Oravainen population. In addition to normal males and females, virtually every nest produced a considerable number of mosaic gynandromorphs. This seems to be a regular situation for this population and already in the pitfall trap material from the year 1966 there was one such specimen. Jacobson (1939, as M. rolandi) mentioned the occurence of gynandromorphs in the east Baltic colonies of this species.

\section{Myrmica hellenica Forel, 1913 (Map 2)}

This species is new to Finland. Some 7 nests were found 21.VII.1988 in Hanko, Kolaviken during a collecting trip made by the author and Dr. Perttu Seppä $\left(60^{7} 0^{7} 7 \bigcirc \bigcirc 1 \varnothing, \mathrm{MZT}\right)$. The site was revisited on 19.VII.1994 by the author and one nest was

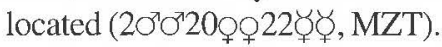

The nests were buried some $10 \mathrm{~cm}$ in the sand and had a single entrance. They were about 50 meters from the waterline. The area is regularly visited by people and the trampling effect is con- 
siderable. The habitat is in good agreement with that given by Seifert $(1988,1993 b)$ for this species.

\section{Myrmica hirsuta Elmes, 1978 (Map 3)}

In Central Europe this widely spread social parasite lives in the nests of $M$. sabuleti, while in Finland it is found in the nests of its sister species $M$. lonae. The species was recorded as new to Finland by Vepsäläinen \& Pisarsky (1982) from Hanko, Tvärminne. At present, the species is known from three places in Finland:

1. Tammisaari, O. Wellenius leg.: 1935,1937 , 1938, 1945 (MZT: 10'1 DAZH: $\left.20^{7} 0^{7} 3 \circ Q\right)$

2. Hanko, Tvärminne (Vepsäläinen \& Pisarsky 1982)

3. Nauvo, Seili, M. Saaristo leg.: 1983 (1),

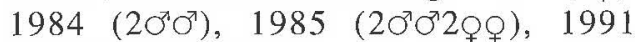
(400 $\left.0^{7} 9 \circ \circ\right)(\mathrm{MZT})$

\section{Myrmica lobicornis Nylander, 1846 (Map 4)}

This is a fairly common species in Finland and well distributed up to about the level of $69^{\circ} \mathrm{N}$. It apparently avoids places inhabited by man although it benefits from the human activities by nesting frequently on road sides, in the surroundings of gravel pits, the bases of winter roads etc. The species is not abundant anywhere, and avoids both very dry and very wet places. The nests are mostly buried in the soil and there is usually one queen and less than 500 workers.

\section{Myrmica lonae Finzi, 1926 (Map 5)}

In Finland this species has been currently identified as $M$. sabuleti Meinert, 1861. However, already Collingwood (1979) noticed that in the Scandinavian populations of this species the basal part of the scape is extraordinarily strongly developed, which is characteristic of $M$. lonae. In accordance with the opinion of Seifert (1993b) the latter name is used here for the Finnish populations of this species.

Like its sister species $M$. sabuleti, $M$. lonae is an interesting species used as a host not only by $M$. hirsuta, but also a lycaenid butterfly, Maculinea arion (Linnaeus, 1758), is obligatorily dependent on it. In Finland this butterfly is listed as a highly threatened species and it is also protected by the law.

In the Finnish inland $M$. lonae is found only on eskers, ie. postglacial moraine ridges, but in the SW-archipelago in various kinds of habitats, often in very hot and dry places. The nests are either under stones or buried in the soil. There are several queens in the nest and up to 1000 or ever more workers.

\section{Myrmica rubra Linnaeus, 1758 (Map 6)}

This is one of the most common Myrmica species in Finland although, as being a typical lowland species, its range is limited to about $66^{\circ} 40^{\prime} \mathrm{N}$. It is also a very aggressive species and stings freely. It is found in a large variety of habitats but is comparably rare inside larger forests, where it is displaced by its sibling species $M$. ruginodis. 'The species is frequent in gardens and acricultural meadows; especially in very moist seashore meadows it may be locally extremely abundant. It tolerates growth of grasses and other field layer plants much better than other ants. Nests are normally polygynous with some 1000 workers, but it may develop huge monocalic colonies covering up to $2 \mathrm{~m}^{2}$ and consisting of hundreds of queens and over 10000 workers. $M$. rubra tends aphids more frequently than other members of the genus. It also climbs among lower vegetation and is frequently found collecting floral nectar, especially on the inflorescence of umbelliflorae. Trees are also visited in search of aphids and coccids. Until recently, it was commonly thought that the species quite frequently had so-called microgynes in its nests. However, several authors (Elmes 1976, Pearson \& Child 1980, Pearson 1981 and Elmes \& Brian 1991) have been able to show that these microgynes are in fact reproductively isolated social parasites of $M$. rubra, and accordingly the species was formally described by Seifert (1993a) as M. microrubra.

\section{Myrmica microrubra Seifert, 1993 (Map 7)}

This social parasite of $M$. rubra is new to Finland and, at present, has been verified from the following three places: 

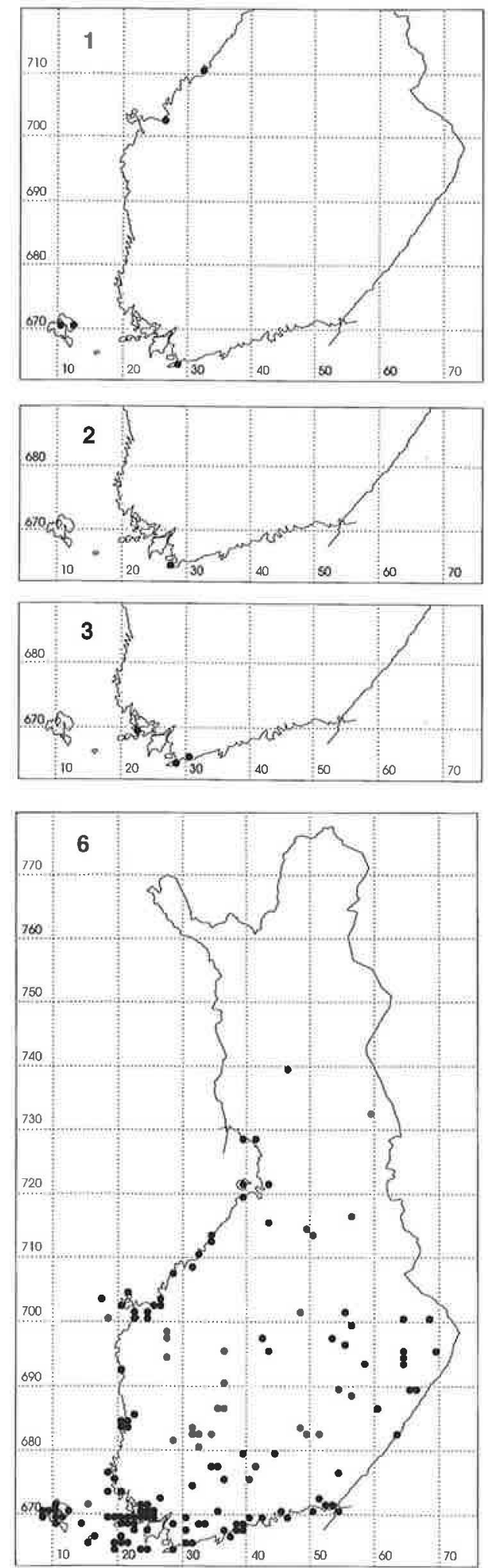
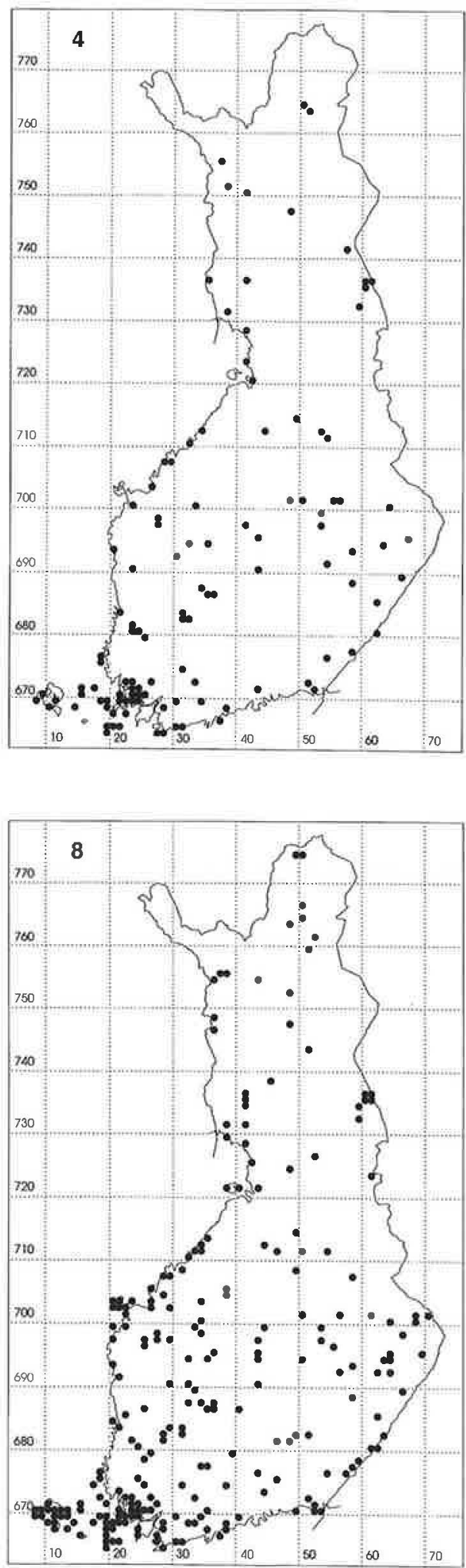

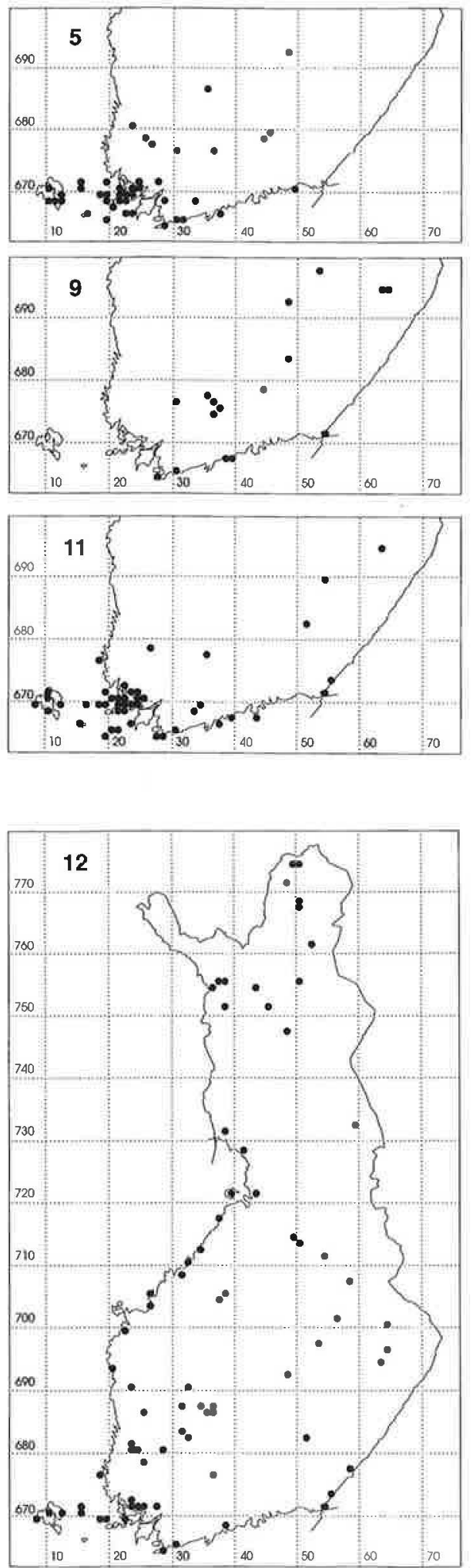
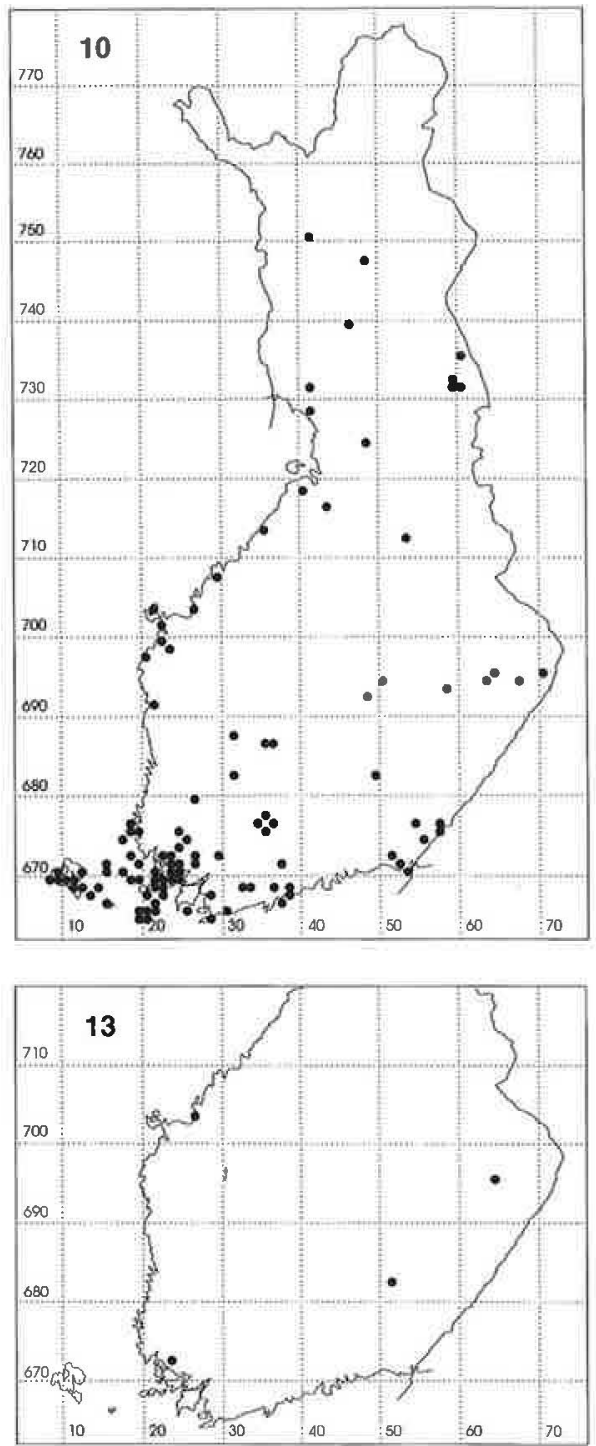

1. Turku, Rauvola, 1985, 1986, numerous $0^{7} 0^{7}$ of, leg. M. Saaristo (MZT)

2. Pohja, Finskari, 1989, $10^{\top 1} 1$, leg. J. Perkiömäki (MZT)

3. Hanko, Tvärminne, Biol. Stat., 1991, 1o, leg. P. Seppä (MZT)

The occurence of $M$. microrubra seems to be independent of the nesting site of the host species. In Rauvola the host nested in a large, rotten birch $\log$ in an oak groove; while in Trärminne the nest was buried in the ground on an open field. 
Myrmica ruginodis Nylander, 1846 (Map 8)

This is the most common Myrmica species in Finland and is found throughout the country. It is a typical woodland species, but is also found on moorlands and bogs. Contrary to its sibling species $M$. rubra, $M$. ruginodis apparently avoids places with strong human influence. Nests are frequently found inside moss hummocks, but also under stones and in rotten wood.

\section{Myrmica rugulosa Nylander, 1849 (Map 9)}

At present the species has been recorded only from 14 places in Finland. In Finland the species is strongly confiend to eskers and other sandy areas. It is quite tolerant to human activities and e.g. in the city of Heinola dozens of nests were found in the lawns of the central park 20.VI.1988. Unlike other escer species, $M$. rugulosa have not been found in the SW-archipelago.

The nests of this species are deep in the ground with a circular crater-like opening. Blowing into the opening will cause the workers to pour out of the nest in large numbers. The species may be very abundant locally, as was the case in Joensuu.

The Joensuu population was originally found by K. Vepsäläinen in 1978. It was revisited in 1987. At that time hundreds of nests were found in a park in the middle of the town along the river bank. Short dense grass covered the site but the above mentioned blowing method made it easy to locate the nests.

\section{Myrmica scabrinodis Nylander, 1846 ( Map 10)}

This species is most often an inhabitant of bogs in Finland making its nest among Sphagnum. It is also found at edges of moist fir-forests nesting in moss hummocks or in rotten pieces of wood. At least in southwestern Finland, M. scabrinodis is also found on very dry and warm rock slopes, where it nests under stones. The species may also live in meadows, being then closely associated with mound nests of Lasius flavus and exploiting its brood as a protein source. On bogs $M$. scabrinodis may be very abundant, while densities in other habitats are relatively low. Usually there is one or a few queens in individual nests with a few hundred workers, but quite often larger nests with some 2500 workers can be found.

\section{Myrmica schencki Emery, 1894 (Map 11)}

This is a thermophilic species living in Finland in much the same kind of habitats as $M$. lonae. The nests are fairly small, usually consisting of some $300-400$ workers and up to 5 queens. The nests may be under stones or buried in the soil. In the later case there may be $1-4$ entrances with small chimney-like vertical extensions made of small vegetable particles.

\section{Myrmica sulcinodis Nylander, 1846 (Map 12)}

This species preferes well drained more or less sandy places. Like most of our myrmicids $M$. sulcinodis avoids places inhabited by man, though it is frequently found on roadsides, surroundings of gravel pits, bases of winter roads etc. The nests are usually buried in the soil or sometimes built under stones. They are fairly small including up to 500 workers and usually a single queen.

\section{Symbiomyrmakaravajevi Amoldi, 1930 (Map 13)}

At present the species has been recorded in four different places:

1. Ristiina (Collingwood 1979)

2. Kontiolahti (Saaristo 1986)

3. Masku, Karevanrahka, 1966, 1q, leg. S. Koponen (MZT)

4. Oravainen, kk., 7.VIII.1985, numerous ơợo, leg. M. Saaristo (MZT)

No details are known about the sample mentioned by Collingwood (1979). The females from Kontiolahti and Masku were collected by pitfall traps on bogs together with numerous workers of M. scabrinodis. In Oravainen plenty of males and females were collected from a nest of $M$. scabrinodis together with the sexuals of the host species. The nest was situated in a high Sphagnum hummock at the edge of a small bog. In the same area there were numerous other nests of $M$. scabrinodis. It is quite 
possible that $S$. karavajevi can be found in Finland on any given bog where a sufficiently strong population of M. scabrinodis occurs.

Contrary to the opinion of Bolton (1988), I agree with Seifert (1993a) and consider Symbiomyrma as an independent genus distinctly separated from Myrmica.

\section{Leptothorax acervorum (Fabricius, 1793) (Map 14)}

This is perhaps the most common and eurytopic ant species in Finland. It can be found in all kind of habitats except parks and cultivated areas. The nests are usually built inside more or less rotten twigs and other kind of wood, sometimes under bark and in standing tree stumps. More rarely they are under stones, while on bogs the nests are quite often in peat.

Nest densities can be locally quite high; the nests are often occupied by several queens and usually some $60-80$ workers, but nest containing even 200 workers can be found. The species tends to darken in colour from south to north and also the members of the colonies living on bogs are darker than those nesting in dryer places. In Fell Lapland the species is very darkly coloured and clearly larger than in the more southem places; the northern workers are about the same size as the southern queens.

\section{Leptothorax interruptus (Schenck, 1852) (Map 15)}

The species is new to the Finnish fauna and now known from seven places:

1. Karjalohja, date unknown, some o7 ơ J. Sahlberg (MZT \& MZH)

2. Hanko, Kolaviken, 1.VII.1985, 7ððð, leg. M. Saaristo (MZT)

3. Hanko, Koverhar, 2.VII.1985, 36ðð, leg. M. Saaristo (MZT)

4. Hanko, Tvärminneby, 13.VII.1986,

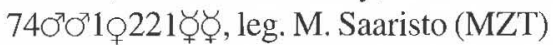

5. Liperi, Ylämylly, 17.VII.1987, 1@79фð, leg. M. Saaristo (MZT)

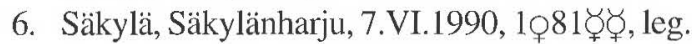
M. Saaristo \& V. Rinne (MZT)

7. Dragsfärd, Sandö, 1991, 1ø, leg. V. Rinne (MZT)

According to Seifert (1993b), this is a quite thermophilic species and in Finland it has been found only on eskers where it seems to prefer open, sunny places with fairly patchy vegetation. Nests are buried some $5-8 \mathrm{~cm}$ deep in the sand and have a single opening. They are difficult to locate as they are usually under more or less dense undergrowth, e.g. Empetrum or Arctostaphus stands; in Säkylä the nest was among the roots of Antennaria dioeca. The nest consists of a single queen and some 50 to over 200 workers.

\section{Leptothorax kutteri Buschinger, 1965 (Map 16)}

This workerless social parasite is new to Finland and found already in 18 different places. It can be found practically in any place where its host species, $L$. acervorum, has a suffiently dense population. However, the northern limit for $L$. kutteri seems to be limited the timber line.

Morphology and size of L. kutteri seem to be somewhat variable between different populations, and the case may include more than one taxon.

\section{Leptothorax muscorum (Nylander, 1846) (Map 17)}

This is a quite common species in Finland living much in the same kind of habitats as $L$. acervorum, but it has not been found in bogs. Its range is also much more southern, with the northernmost limit at approximately $64^{\circ} \mathrm{N}$. In southwestern Finland (both inland and archipelago) $L$. muscorum often nests under (small) stones rather than in rotten wood pieces.

\section{Lepthothorax tuberum (Fabricius, 1775) (Map 18)}

The distribution and habitat preference of this species are somewhat different from those of the preceeding species. It is mainly found in the SWpart of Finland and it is quite abundant, especially in the SW-archipelago and Alandian Islands. All inland records come from the esker areas. The species mainly nest in warm places, like rocky hills and sandy road banks. The nest is usually under a small stone and the queen and the workers form a small cluster, often around a plant root. I have, however, found a few nests in rotten pine, as well. On the Hanko peninsula, which belongs to the esker system, the nests were also established in sand, and once a nest of $L$. tuberum was only ca. 

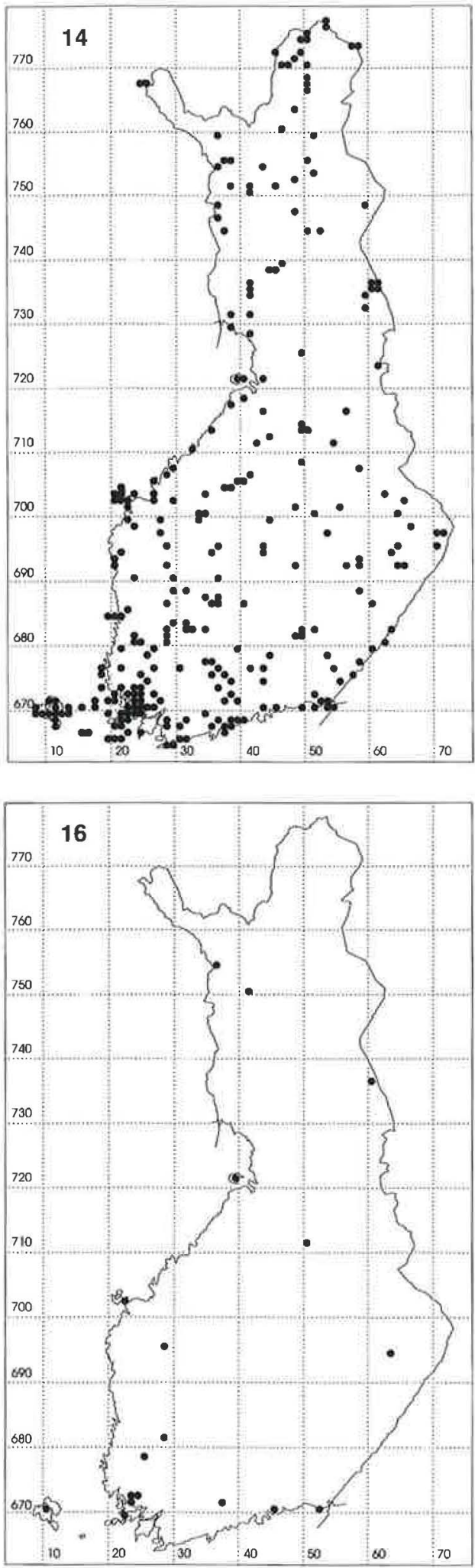
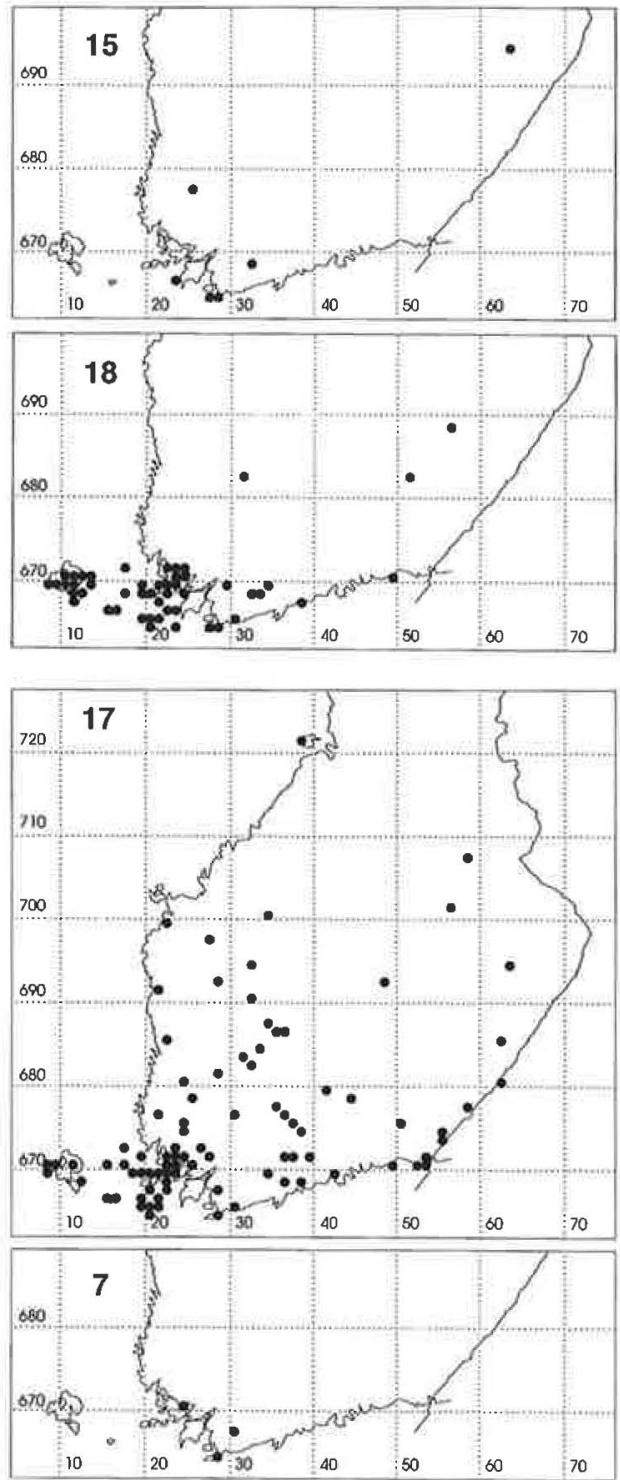

one meter from that of $L$. interruptus. The colony usually consists of about one hundred workers, but I have found nests with well over two hundred workers. According to present knowledge, $L$. tuberum is mainly monogynous in Finland.

Harpagoxenus sublaevis (Nylander, 1849) (Map 19)

This obligatorily dulodic species is fairly common in Finland and is spread throuhgout the country. At present, it has been recorded from 80 different $10 \times$ 

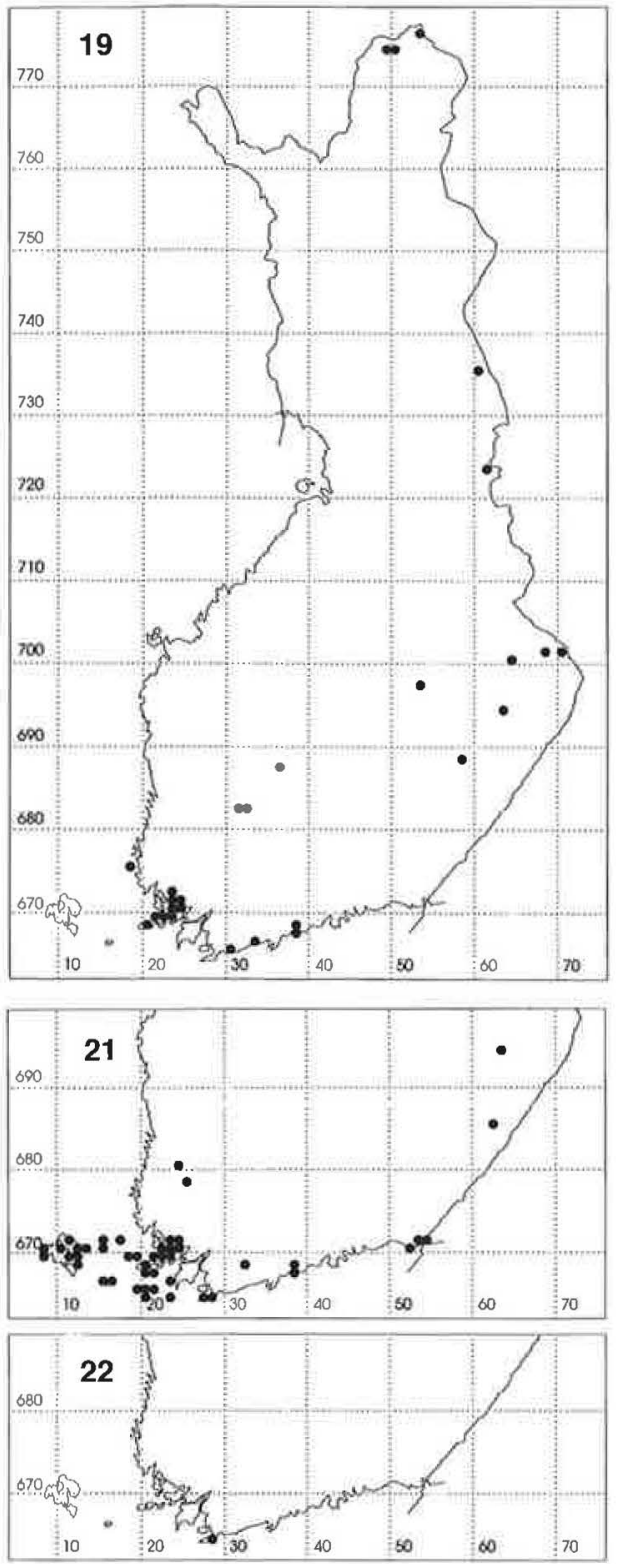

$10 \mathrm{~km}$ squares. Its usual slave species is $L$. avervorum, but sometimes also L. muscorum or even both species are used. In Finland, H. sublaevis has been found nesting only in rotten wood.

Formicoxenus nitidulus (Nylander, 1846) (Map 20)

This xenobiotic species is found only in nests of the red wood ants, Formica rufa, and allied mound building species. Its nests are small and build in

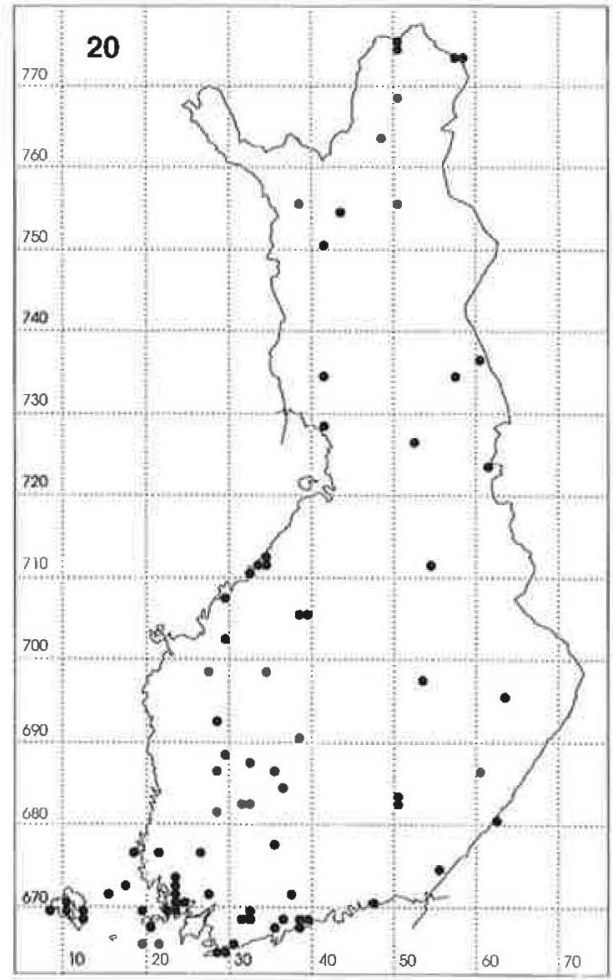

wood or in the earth floor of Formica mounds. It may be seen wandering freely on the mound surface and even several meters away from the host's nest on their foraging trails.

The species is apparently spread throuhgout the country. The low number of sample places is due to the sampling error, as only in few places time allowed checking of its presence.

Tetramorium caespitum (Linnaeus, 1758) (Map 21)

In Finland, this species seems to be predominantly a coastal species, but is found also inland, especially on eskers and other open sandy areas. The general distribution of this species in Finland is comparable to that of $L$. tuberum.

The species tends root aphids, which are readily carried to safety at the slightest disturbance.

Anergates atratulus (Schenck, 1852) (Map 22)

This workerless parasite of $T$. caespitum was recorded as new to Finland by Vepsäläinen \& Pisarsky (1982). Several males and females were collected 
by Pisarsky from a small island called Jovskär just opposite to the Tvärminne Biological Station on the Hanko peninsula. Unfortunately, no specimens were deposited in any Finnish collection.

Acknowledgements. I wish to thank Prof. A. Buschinger (Darmstadt, Germany), Dr. Cedric Collingwood (Leeds, England), Dr. Per Douwes (Lund, Sweden), Dr. Graham Elmes (Dorset, England), Dr. Bernhard Seifert (Görlizt, Germany), Mr. Peter Werner (Prague, Czech), and D: : Donat Agosti (Zürich, Switzerland) for kindly providing me with reference material on several species. I am also greatly indebted to the following persons who arranged loans of material from their institutions: Dr. Cl. Besuchet (Genéve, Switzerland), Dr. Michel Brancucci (Basel, Switzerland), and Dr. Valter Reineri (Genova, Italy). During the collecting trips I recieved various kinds of help from the following persons: Dr. Kari Vepsäläinen, Dr. Perttu Seppä, Mr. Seppo Koponen, Mr. Veikko Rinne, and Mr. Juha Saaristo; I am grateful to all of them.

\section{References}

Collingwood, C. A. 1979: The Formicidae (Hymenoptera) of Fennoscandia and Denmark. - Fauna Entomol. Scand. 8:1-174. Klampenborg, Denmark.

Elmes, G. W. 1976: Some observations on the microgyne form of Myrmica rubra L. - Insectes Sociaux 23:3-22.

Elmes, G. W. \& Brian, M. V. 1991: The importance of the egg-mass to the activity of nonmal queens and microgynes of Myrmica rubra L. (Hym. Formicidae). - Insectes Sociaux 38:51-62.

Jacobson, H. 1939: Die Amaisenfauna des ostbaltischen Gebietes. - Z. Morph. Ökol. Tiere 39:389-454.

Pearson, B. 1981: The electrophoretic determination of Myrmica rubra microgynes as a social parasite: possible significance in the evolution of ant social parasites. In Howse, P. E. \& Cement, J. L. (eds.): Biosystematics of Social Insects, London, New York, pp. 75-84.

Pearson, B. \& Child, A. R. 1980: The distribution of an estrase polymorphism in macrogynes and microgynes of Myrmica rubra Latreille. - Evolution 34(1):5-109.

Saaristo, M. I. 1986: The fourth record of Sifolinia karavajevi (Arnoldi) (Hym., Formicidae) from the Nordic countries. - Notulae Entomol. 66:97-98.

Seifert. 1988: A taxonomic revision of the Myrmica species of Europe, Asia Minor, and Caucasia (Hymenoptera, Formicidae). - Abh. Ber. Naturkundemus. Görlitz 62(3):175.

- 1993a: Taxonomic description of Myrmica microrubra n. sp. - a social parasitic ant so far known as the microgyne of Myrmica rubra (L.). - Abh. Ber. Naturkundemus. Görlitz 67(5):9-12.

- 1993b: Die freilebenden Ameisenarten Deutschlands (Hymenoptera: Formicidae) und Angaben zu deren Taxonomie und Verbreitung. - Abh. Ber. Naturkundemus. Görlitz 67(3):1-44.

Vepsäläinen, K. \& Pisarski, B. 1982: Assembly of island ant communities. - Ann. Zool. Fennici 19:327-335. 